\title{
Recent variation of the Las Vacas Glacier Mt. Aconcagua region, Central Andes, Argentina, based on ASTER stereoscopic images
}

\author{
M. G. Lenzano ${ }^{1,2}$, J. C. Leiva ${ }^{1,3}$, and L. Lenzano ${ }^{1,2}$ \\ ${ }^{1}$ Instituto Argentino de Nivología, Glaciología y Ciencias Ambientales (IANIGLA) - CONICET, Mendoza, Argentina \\ ${ }^{2}$ Instituto de Geodesia y Geodinámica, UNCuyo, Mendoza, Argentina \\ ${ }^{3}$ Facultad de Ciencias Agrarias, UNCuyo, Mendoza, Argentina
}

Received: 4 May 2009 - Revised: 28 December 2009 - Accepted: 28 December 2009 - Published: 27 January 2010

\begin{abstract}
This work presents the results of the ASTER stereoscopic image processing to calculate the volume changes of Las Vacas Glacier. The processing of medium resolution satellite images (ASTER level $1 \mathrm{~A}$ - pixel $15 \mathrm{~m}$ ) from February 2001 and 2007 was performed applying the satellite digital photogrammetry method (Kääb, 2005). The comparison of the two generated DTM returns results that are acceptable within the parameters and precisions that can be obtained with this kind of sensor and the processing methodology.
\end{abstract}

\section{Introduction}

The glaciers of the Andes of the Mendoza province are important as fresh water reservoirs. The knowledge of their present state and climatic change impacts on their evolution will be very useful for water management in the region.

This work shows the preliminary results of the Aster stereoscopic image processing that allowed the authors to calculate the volume changes of the Las Vacas Glacier. There are previous works on the study of the evolution of the frontal position of the glacier, but not on the altimetric changes of the ice body (Espizúa and Maldonado, 2007). The processing of mean resolution satellite images (Aster - pixel resolution $15 \mathrm{~m}$ ) from 26 February 2001 and 13 February 2007 was performed applying the satellite digital photogrammetry method (Kääb, 2005).

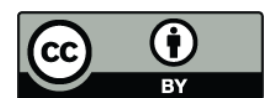

Correspondence to: J. C. Leiva (jcleiva@lab.cricyt.edu.ar)

\section{Study area}

The study area is located within the Parque Provincial Aconcagua, a natural protected area, located around $32^{\circ} 29^{\prime} \mathrm{S}, 70^{\circ} 00^{\prime} \mathrm{W}$ (Fig. 1). Las Vacas Glacier, situated North from Mt. Aconcagua summit, flows to the East from $5500 \mathrm{~m}$ a.s.l. reaching $3700 \mathrm{~m}$ a.s.l. in its lower part. It has an area of approximately $18 \mathrm{~km}^{2}$ (Fig. 2).

\section{Methodology}

In order to obtain the digital terrain models from Aster stereoscopic images, level 1A, corresponding to 2001 and 2007 (Etzelmüller and Sulebak, 2000), the authors priorly selected, the terrain control points on the images, in relation to the size and shape of the area to be modeled. The control points were measured in the field, using GPS Geodetic quality receivers in differential method. The GPS data obtained were processed by linking them to the GPS continuous stations of the SIRGAS net (Drewes, 1998; Fortes et al., 2006) to ensure more reliability $(\Delta \varphi=0.30 \mathrm{~m}, \Delta \lambda=0.30 \mathrm{~m}$, $\Delta z=0.50 \mathrm{~m}$ ). The coordinates thus obtained were referred to the POSGAR (Posicionamiento Geodésico Argentino) reference frame (Cimbaro et al., 2007; Lauria, 2009). Once the data were processed and adjusted, we converted the coordinates to the Gauss Krüger plane projection system, Band 2 $(\mathrm{X}, \mathrm{Y})$. The calculated coordinates served as territorial base for the generation of the stereoscopic models.

The photogrammetric processing of models, performed with the Photomod 4.1 software (Rozycki et al., 2007; Liba et al., 2009), enabled to carry out the respective internal, external and absolute orientations. It must be pointed out that the models altimetry was generated from ellipsoidal heights associated to the same POSGAR reference frame.

Published by Copernicus Publications on behalf of the European Geosciences Union. 


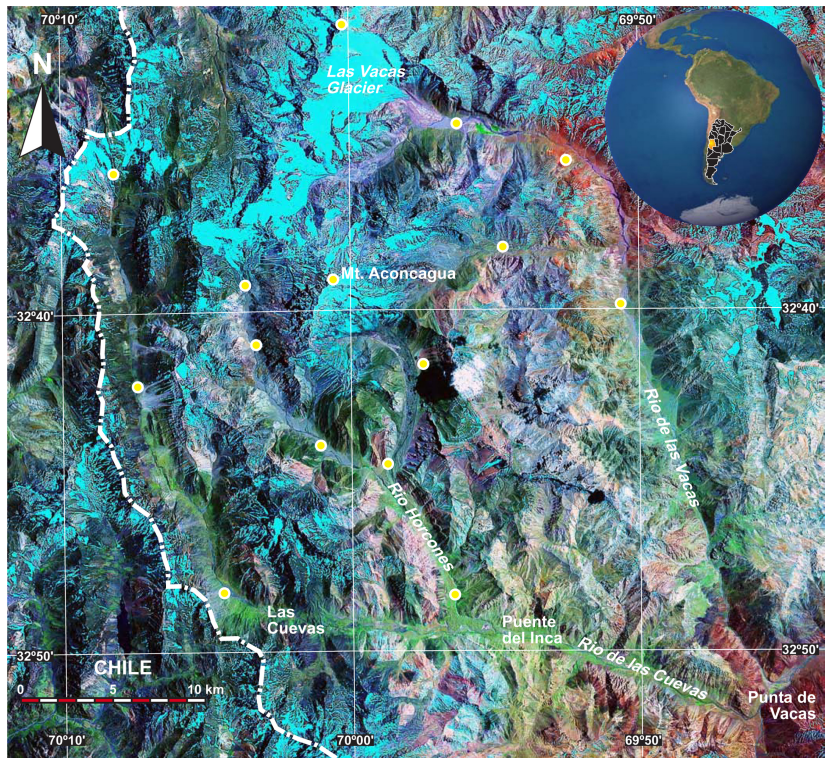

Fig. 1. Location of the study area. Locations of GCPs are shown as yellow dots.

The advantage of working with ellipsoidal heights is that it permits correlating data from different latitudes, at different times, maintaining the maximum altimetric and geodetic precision (Mackern et al., 2007).

Once the virtual models were obtained, the authors were able to generate the TIN (triangular irregular network) mesh, perfectly adapted to the terrain, obtaining level curves each $50 \mathrm{~m}$. Another product derived from the model was the digital elevation model (DEM) generated from a $15 \mathrm{~m}$ cell for both time slices. The vertical accuracy of DEM data was evaluated using high accuracy GCPs to about $\pm 20 \mathrm{~m}$ (Fujisada et al., 2005; Toutin, 2008).

In order to obtain differences between the generated models we took the model of 2001 as a base and, starting from it, we correlated all data obtained afterwards (2007). The values of the altimetric coordinates $(\mathrm{Z})$ of the 2001 model were transferred to build the 2007 model, thus the method errors were minimized (Vignon et al., 2003).

Longitudinal profiles (taking a point each $50 \mathrm{~m}$ ) on the TIN, following the glacier's flow line were extracted. Comparing the longitudinal profiles we were able to retrieve the variation in height of the ice surface between the years 2001 and 2007 (Berthier et al., 2007). In order to reduce distortions between the multi-temporal product the two DEMs were adjusted as one block precisely connected by tie-points as suggested by Kääb et al. (2002b).

The volumetric variations of Las Vacas Glacier were determined comparing the digital elevation models (DEM) of the analyzed seasons. The software allowed to use a $50 \mathrm{~m}$ grid, create square prisms and by comparing them, we obtained the variation of the ice volume between the dates considered.

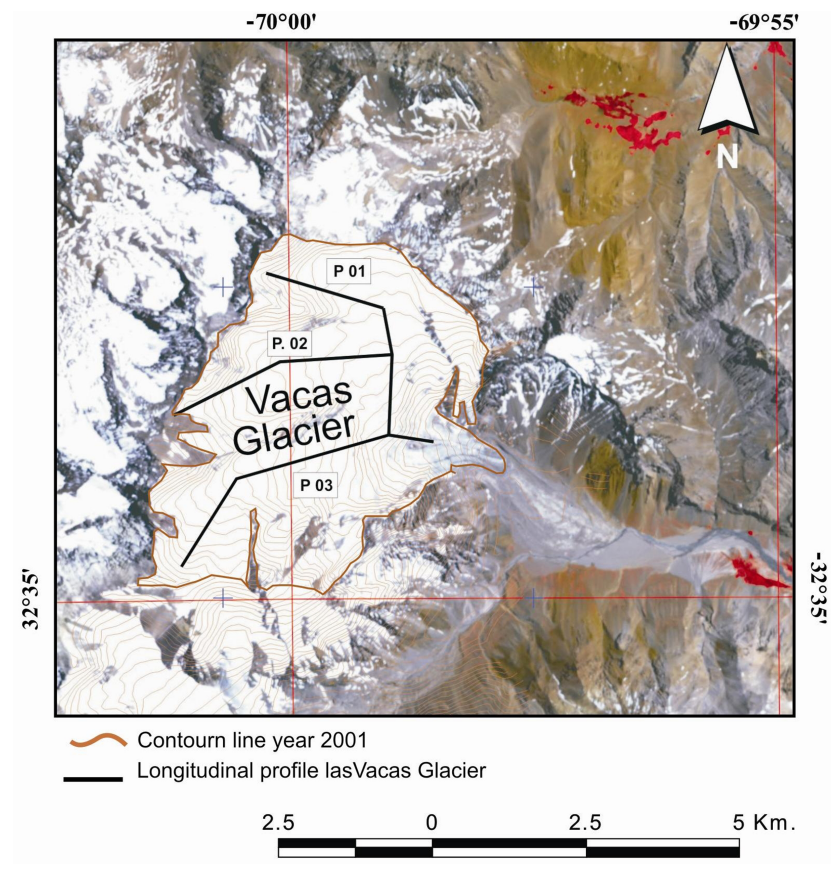

Fig. 2. Profiles along flow lines of Las Vacas Glacier.

The obtained ice surface altimetric variation data, $\Delta z$, were put into a planimetric satellite map (scale 1:50 000), orthorectified from the 2001 DEM generated from the ASTER scene according to Hirano et al. (2002).

\section{Results}

Aided by the digital terrain models (DEM) we planimetrically compared the situation of the ice body in 2001 and 2007 as shown in Kääb et al. (2002a). Figure 3 shows the ice surface elevation in 2001 and 2007 taken along profiles along the ice bodies. These were manually drawn so that their position follows the central line of the ice flow. Table 1 shows the mean $\Delta z_{01-07}$ for each profile.

The average ice elevation change for the three profiles between 2001 and 2007 is approximately of $-35 \mathrm{~m}$ on Las Vacas Glacier. The 2001-2007 volume variation is $\Delta V_{01-07}=-0.64 \mathrm{~km}^{3}$ occurring in a glacial surface of $18.4 \mathrm{~km}^{2}$ in 2001 . The Las Vacas Glacier accumulated net mass balance 2001-2007 is negative even if the glacier has shown ice gain in the accumulation zone. During the same period the overall Las Vacas Glacier surface lowered by $10 \%$.

Glaciological studies performed at the Piloto East Glacier, located $16 \mathrm{~km}$ West from Las Vacas Glacier in a nearby valley, show that the same receding process that has taken place in almost every glacier since at least the beginning of the 20th century in this area still continues on both sides of the Cordillera (Leiva et al., 2007a, 2008; Bown et al., 2008). 

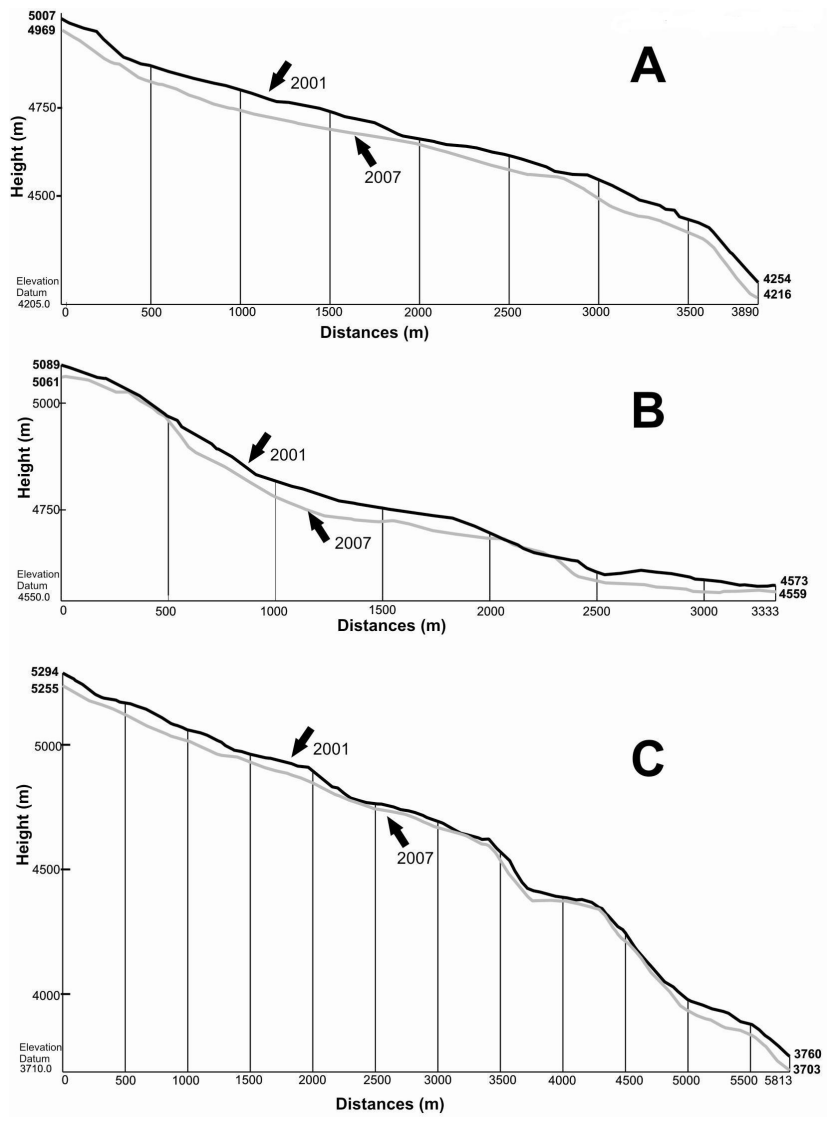

Fig. 3. Ice surface elevation of Las Vacas Glacier in 2001 and 2007. (A) Las Vacas Glacier profile \#1. (B) Las Vacas Glacier profile \#2. (C) Las Vacas Glacier profile \#3.

Data from meteorological stations of Central Chile showed a warming of 0.3 to $0.7^{\circ} \mathrm{C}$ over the last hundred years, with a greater increment in winter than in summer (Escobar and Aceituno, 1998; Carrasco et al., 2008). The analyses of the $0^{\circ} \mathrm{C}$ isotherm at the Quintero station $\left(32^{\circ} 47^{\prime} \mathrm{S}\right.$, $71^{\circ} 33^{\prime} \mathrm{W}$; $8 \mathrm{ma.s.1}$.) highlighted a $150 \mathrm{~m}$ vertical rise of this isotherm in winter and $250 \mathrm{~m}$ in summer over the last 25 years. This suggests that a similar trend must have affected the snow line in this part of Argentina. At the same time, the frequency of winter precipitation below-average has increased in the last 2-3 decades (Casassa et al., 2003; Leiva et al., 2007b). These facts may explain the 2001-2007 ice mass loss of the las Vacas glacier.

We analyzed temperature and snow accumulation data from Horcones Weather Station, located $24 \mathrm{~km}$ away from Las Vacas Glacier front and at an altitude $900 \mathrm{~m}$ below it.

The daily mean temperature of December, January and February (warmest months) shows no tendency during the 2000-2009 period (Fig. 4a). The daily mean temperature of June, July, August and September (coldest months) (Fig. 4b) show a very slight tendency of cooling. The snow accumulation, in water equivalent; during July, August and September
Table 1. Mean ice elevation change 2001-2007 of Las Vacas Glacier along selected flow lines according to Fig. 2.

\begin{tabular}{cc}
\hline Profile & Mean $\Delta z_{01-07}$ \\
\hline$\# 1$ & $-35 \mathrm{~m}$ \\
$\# 2$ & $-32 \mathrm{~m}$ \\
$\# 3$ & $-37 \mathrm{~m}$ \\
\hline
\end{tabular}

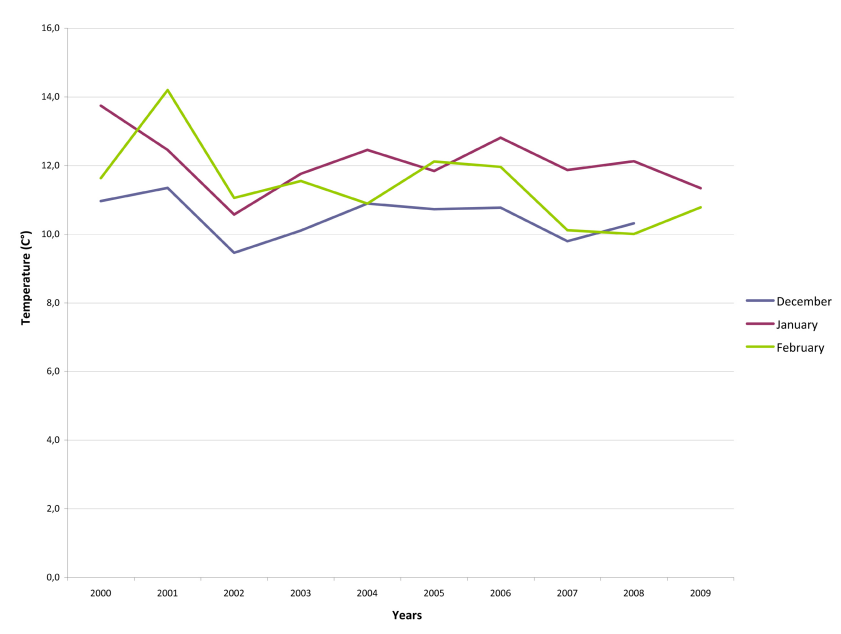

Fig. 4a. Mean monthly air temperature (2000-2009), December, January and February at Horcones Weather Station.

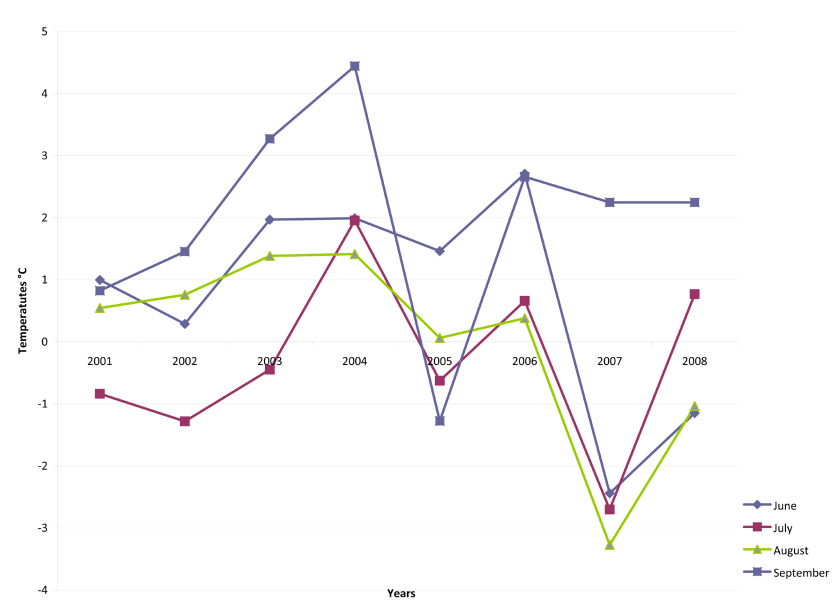

Fig. 4b. Mean monthly air temperature (2000-2009), June, July, August and September at Horcones Weather Station.

(Fig. 5), shows great variability of snow precipitation during the study period. 


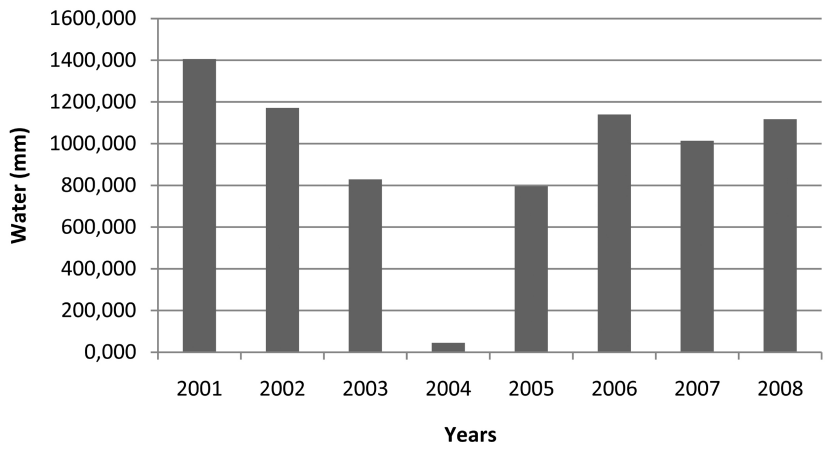

Fig. 5. Snow precipitation at Horcones Weather Station (20012008). Accumulated snow-pillow data in $\mathrm{mm}$ of water equivalent.

\section{Conclusions and discussion}

Las Vacas Glacier represents an important reservoir for the water resource in the Rio Mendoza basin. This is why it is necessary to find out if the employed methodology is suitable to follow the evolution of the ice body in time with the use of methodologies that will yield reliable and efficient results at basin scale. The first results obtained through the used indirect methods show the shrinking of this glacier in recent years.

The Horcones Weather Station data do not explain or reflect the glacier behavior. This may be because of its location, away and below from Las Vacas Glacier, and situated in a valley with different orientation.

Data from ten of fifteen available GCPs were used to adjust the DEM. The Z-coordinates from the remaining five GCPs were compared with its Z-coordinates obtained from the DEM. The mean error is $\pm 24 \mathrm{~m}$, implying that the results of Table 1, as obtained from the DEMs, provide a reliable signal of the thinning process on Las Vacas Glacier. Therefore, the comparison of longitudinal glacier profiles shows results congruent with the regional glaciers behavior.

To corroborate the obtained results it is necessary to calculate the volumetric variations of the glacier by direct methods. The authors also propose to improve the accuracy of the use of ASTER images by increasing the number of GCP. Fujisada et al. (2005), using high accuracy GCPs, evaluated that the vertical accuracy of DEM is about $\pm 20 \mathrm{~m}$ with $95 \%$ confidence $(2 \sigma)$. Also, the use of a DEM created from topographical measurements and aerial photographs with better vertical accuracy (Vignon et al., 2003) as a base for comparison with future DEMs derived from ASTER images would allow to have more confidence in the glacier ice-mass variation assessment.

The suggest measures for further investigations will allow for a better assessment of the temporal and spatial behavior of these glaciers by relating the indirect with the direct methods, given that the indirect methods are a straightforward tool providing access to information from large area that were not investigated until then.

Acknowledgements. The authors are greatly indebted to the following: S. Khalsa Singk and two other anonymous reviewers for the critical reading of the manuscript and advice. Christoph Schneider who acted as co-editor, organized the review process and also helped to substantially improve this paper. R. Bottero, R. H. Bruce, E. Corvalán, the IANIGLA technicians for their help with graphs, figures and field work. M. E. Soler for her valuable help with the English version of this manuscript. This work was partially supported by ANPCYT (the National Agency for Promotion of Science and Technology) Project PID 03 14480, by UNCUYO (National University of Cuyo) Project 06/A320 awarded to JCL and by a CONICET (the Argentine National Research Council) grant awarded to MGL.

Edited by: C. Schneider

Reviewed by: S. J. S. Khalsa and two other anonymous referees

\section{References}

Berthier, E., Arnaud, Y., Kumar, R., Ahmad, S, Wagnon, P., and Chevallier, P.: Remote sensing estimates of glacier of mass balance in the Himachal Pradesh (Western Himalaya, India), Remote Sens. Envirom., 108, 327-338, 2007.

Bown, F., Rivera, A., and Acuña, C.: Recent glaciers variations at the Aconcagua basin, central Chilean Andes, Ann. Glaciol., 48, 43-48, 2008.

Carrasco, J. F., Osório, R., and Casassa, G.: Secular tren of equilibrium line altitude on the western side of the southern Andes, derived from radiosonde and surface observations, J. Glaciol., 54, 538-550, 2008.

Casassa, G., Rivera, A., Escobar, F., Acuña, C., Carrasco, J., and Quintana, J.: Snow line rise in Central Chile in recent decades and its correlation with climate, Geophys. Res. Abstracts, 5, 14395, 2003.

Cimbaro, S. E. and Lauria, E. A.: Adoption of an ITRF 2005 based frame as the National Geodetic Frame of Argentina. Poster presented at IUGG XXIV General Assembly Earth, Our Changing Planet, Perugia, Italy 2-13 July 2007.

Drewes, H.: Time evolution of the SIRGAS reference frame, Springer, IAG Symposia, Vol. 118, 174-179, 1998.

Escobar, F. and Aceituno, P.: Influencia del fenómeno ENSO sobre la precipitación Nival en el sector andino de Chile central durante el invierno, Bulletin de 1'Institute Français d'Etudes Andines, 27(3), 753-759, 1998.

Espizúa L. E. and Maldonado G. I.: Glacier Variations in the Central Andes (Mendoza province, Argentina) from 1896 to 2005, in: Environmental change and rational water use, edited by: Scarpati, O. E. and Jones, J. A. A., Orientación Gráfica Editora S.R.L, Buenos Aires, 458 pp., 353-366, ISBN: 978-987-926046-3, 2007.

Etzelmüller, B. and Sulebak, J. R.: Developments in the use of digital elevation models in periglacial geomorphology and glaciology, Physische Geographie (Vol. 41), Jahrestagung Winterthur, 2000.

Fortes, L. P., Lauria, E., Brunini, C., Amaya, W., Sánchez, L., Drewes, H., and Seemeller, W.: Current status and future de- 
velopments of the SIRGAS project, Wiss. Arb. der Fachr. Vermessungswesen der Univ. Hannover, Nr. 258, 59-70, 2006.

Fujisada, H., Bailey, G. B., Kelly, G. G., Hara, S., and Abrams, M.: Aster DEM Performance, IEEE Transactions on Geoscience and Remote Sensing, 43(12), 2707-2813, 2005.

Hirano, A., Welch, R., and Lang, H.: Mapping from ASTER stereo imagery data: DEM validation and accuracy assessment, ISPRS Journal of Photogrammetry and Remote Sensing, 57(2003), 356370, 2002.

Kääb, A., Huggel, C., Paul, F., Wessels, R., Raup, B., Kieffer, H., and Kargel, J.: Glacier monitoring from Aster imagery: accuracy and applications, Proccedings of EARSeL-LISSIGWorkshop Observing our Cryosphere from Space, Bern, 11-13 March 2002, 43-53, 2002a.

Kääb, A.: Monitoring high-mountain terrain deformation from repeated air- and spaceborne optical data: examples using digital aerial imagery and ASTER data, ISPRS Journal of Photogrammetry and Remote Sensing, 57(2002), 39-52, 2002b.

Kääb, A.: Remote sensing of mountain glaciers and permafrost creep, Physical Geography Series, 48, University of Zurich, 2005.

Lauria, E. A.: República Argentina - Adopción del Nuevo Marco de Referencia Geodésico Nacional POSGAR 07 - RAMSAC, Novena Conferencia Cartográfica Regional de las Naciones Unidas para América, United Nations E/CONF.99/CRP.9, New York, 10-14 August 2009.

Leiva, J. C., Cabrera, G. A., and Lenzano, L. E.: 20 years of mass balances on the Piloto glacier, Las Cuevas river basin, Mendoza, Argentina, Global Planet. Change, 59, 10-16, 2007a.

Leiva, J. C., Cabrera, G. A., and Lenzano, L. E.: Impacts of the Climatic Change on the hydric resources of the cordillera de Los Andes. A study case: evidences, forecasting and consequences in the upper basin of the Mendoza river, in: Environmental change and rational water use, edited by: Scarpati, O. E. and Jones, J. A .A., Orientacin Gráfica Editora S.R.L., Buenos Aires, 458 pp., 377-385, ISBN: 978-987-9260-46-3, 2007b.
Leiva, J. C., Espizùa, L., Iturraspe, R., Masiokas, M., Norte, F., and Villalba, R.: La risposta dei ghiacciai argentini al clima dei secoli XX e XXI - The response of the Argentinian glaciers to the climate of the XX and XXI centuries. In Terra Glacialis - Edizione Speciale - 2008, edited by: Servizio Glaciologico Lombardo, 240 pp., 179-192, ISBN 978-600-1673-13-9, 2008.

Liba, N. and Jarve, I.: Making orthophotomosaic about Tartu city with PHOTOMOD Program and its geometrical quality, FIG 2009 Working Week Report (Fédération Internationale des Géomètres - International Federation of Surveyors) - Surveyors Key Role in Accelerated Development, Eilat-Israel, 3-8 May 2009.

Mackern, V., Lenzano, L., Robin, A. M., and Lenzano, M. G.: Un marco de referencia global para la Industria Petrolera, Neuquén, Geoacta, 31, 81-89, ISNN:0326-7237, 2007.

Rozycki, S. and Wolniewicz, W.: Assessment of DSM accuray obtained by High resolutions stereo images. ISPRS Hannover Workshop 2007 High Resolution Earth Imaging for Geospatial Information, Universität Hannover, Leibniz, Germany, 29 May1 June 2007.

Toutin, T.: ASTER DEMs for geomatic and geoscientific applications: a review, Int. J. Remote Sens., 29(7), 1855-1875, 2008.

Vignon, F., Arnaud, Y., and Kaser, G.: Quantification of glacier volume change using Topographic and ASTER DEMs. A case study in the Cordillera Blanca, in: Proceedings of IGARSS'2003, 2125 July 2003, Toulouse, France, IEEE 2003, 2605-2607, 2003. 